\title{
Impact of Enclosure on Plant Species Composition and Biomass Production in Ewa Woreda of Afar Region State, Ethiopia
}

\section{Mohammed Abdulatife Ibrahim*}

Dubti Pastoral and Agro-pastoral Research Center P.O.Box 16, Semera (Afar), Ethiopia

\begin{abstract}
This study was conducted to know the impact of enclosure on plant covers dynamics and biomass production in Ewa district. A total of 13 species of grasses, 2 species of legumes, and 4 species of other herbaceous plants were identified in both grazing areas. Of the grass species, $15.3 \%, 30.8 \%, 38.6 \%$ and $15.3 \%$ were highly desirable, desirable, less desirable and undesirable respectively. The grass species dominant in communal grazing areas were Chryspogon plumolosus (22.1\%) and Tragus beteronianus (20.6\%) whereas Cenchrus ciliaris (21.2\%) was dominant in the enclosure area. A higher $(\mathrm{P}<0.05)$ total grass biomass production and total herbaceous biomass production were obtained in the enclosure areas than in communal grazing areas while in case of non-grass biomass production, there was no any significant different $(\mathrm{P}<0.05)$ between the two grazing areas. In general, the result showed that in species composition and biomass production communal grazing areas have deteriorated which may need an immediate intervention, while the enclosure areas need a sustainable conservation of their present condition by considering alternative management that allows selectively and carefully timed utilization.
\end{abstract}

Keywords: Enclosure; Plant cover; Biomass production; Grazing areas

\section{Introduction}

In Afar region livestock are mainly depend on communal rangeland, which are over-grazed and invaded by poor quality grasses and noxious tree species. The quantity and quality of these feed resources is very poor to meet feed requirements of the livestock. As a result, productivity of the livestock is very low. Overgrazing is the main anthropic factors leading to the deterioration of the perennial plant cover. Its negative effect is excessive removal of the living parts of the high range value species, which may lead to their extinction. This factor is being more harmful when coupled with the climate aridity effect. Most of the grazing areas of Afar region are exposed to overgrazing because of this the availability of animal feed decline both in quality and quantity, therefore making excluding livestock from the grazing areas causes an improvement in the rangeland condition and turn lead to improvements in fodder and also compared to unenclosed land, range enclosure provide more feed and as result livestock produce more milk.

According to the report of [1] Making enclosure and herd management follows rotational and/or deferred grazing patterns were the common practiced of Afar community in previous decades, it implies that overgrazing is prohibited by traditional institutions but now due to aggravated pressure (i.e., overgrazing, population increment and weakening of the traditional institutes) no one has been tried to implement the traditional range rehabilitation practices. In principle the pastoralists have been known about the merit of making enclosure in terms of biomass production but they didn't have any interest to materialize their knowledge. Now efforts have been made by GOs and NGOs to internalize the use and advantage of making enclosure through demonstration and awareness rising by giving technical support.

Recently, so money pastoralists in Ewa district are started to enclosure the communal grazing areas by using different local material available in the area so, the present study will be carried out to assessing the impact of rangeland resting (enclosure) on plant species composition and biomass production in Ewa site.

\section{Objective}

Specific objective of the study:

- To assess the species composition in both communal and enclosure areas

- To know the biomass production in the communal and enclosure areas

\section{Material and Methods}

\section{Case study area}

The study was undertaken in Ewa district of zone one (Fente Resu) of the Afar Regional State. The total land area of the district is about 132,700 ha of which the largest area is rangeland [2]. The climate is characterized as arid and semi-arid agro-ecological area and the average temperature of the area is about $28^{\circ} \mathrm{C}$. The rainfall is bimodal with erratic distribution, with the long rainy season (Kerma) is between Mid-June to Mid-September and the short rainy season (Sugum) that occurs between March and April. The dominant soil types in these areas are sandy, vertisoils and deposits of silt and fine sand particles [2]. In most of the study area, the topography is lowland plains, but there is also hilly escarpment in the western edges with the neighboring Amhara region.

\section{Sampling procedures}

Site selection and layout: The grazing areas were stratified as

*Corresponding author: Mohammed Abdulatife Ibrahim, Dubti Pastoral and Agro-pastoral Research Center, Semera (Afar), Ethiopia, Tel: 2513366604; E-mail: amame120@yahoo.com

Received April 11, 2015; Accepted January 11, 2016; Published January 18, 2016

Citation: Ibrahim MA (2016) Impact of Enclosure on Plant Species Composition and Biomass Production in Ewa Woreda of Afar Region State, Ethiopia. J Biodivers Endanger Species 4: 157. doi:10.4172/2332-2543.1000157

Copyright: (c) $2016 \mathrm{Ibrahim} \mathrm{MA}$. This is an open-access article distributed under the terms of the Creative Commons Attribution License, which permits unrestricted use, distribution, and reproduction in any medium, provided the original author and source are credited. 
Citation: Ibrahim MA (2016) Impact of Enclosure on Plant Species Composition and Biomass Production in Ewa Woreda of Afar Region State, Ethiopia. J Biodivers Endanger Species 4: 157. doi:10.4172/2332-2543.1000157

communal grazing and enclosure, which represent the major grazing areas of the pastoral community. The sampling procedure was stratified random sampling technique [3]. The numbers of sampling blocks were 4 from communal grazing, and 2 from enclosure areas. The allocation of range block is based on the grazing potential and the availabity of rangeland (proportional sampling method). In each range site, a sampling block of $200 \mathrm{~m}$ by $100 \mathrm{~m}$ was demarcated and further stratified into two sample plots of equal size based on landscape. This sample plots were divided in to four equal areas $\left(50 \times 50 \mathrm{~m}^{2}\right)$, from each areas 5 quadrants were randomly taken to know the biomass production of herbaceous species and this 5 quadrants used as one range site. Vegetation composition assessment was conducted during the main rainy season of 2011 G.C the time when most of the plants are at their flowering stage.

Species composition: Plant species composition of the herbaceous layer at each sample site was determined by using a wheel point apparatus based on the frequency of occurrence of the species and a minimum of 300 point observations were recorded at the interval of 3 $\mathrm{m}$ by revolving the wheel-point Tidmarsh and Havenga, 1955. At each observation point, the nearest herbaceous species within a radius of $300 \mathrm{~mm}$ was recorded. If no herbaceous species occur within the given radius of the point, it was recorded as "bare ground". The identified herbaceous species were classified into groups using the desirability groups, they were divided into four groups, i.e., highly desirable, desirable, less desirable and undesirable. Moreover, the frequency classification was according to the method of [4], such as Present $(<10 \%)$, Common $(10 \%$ and $20 \%)$ and Dominant $(>20 \%)$.

Dry matter Production: In each of the sample plot, the herbaceous vegetation was harvested at ground level using hand shears from five randomly placed quadrate. Each $1 \mathrm{~m} \times 1 \mathrm{~m}$ quadrate was used to assess the dry matter biomass production. The herbaceous species were divided into grasses and non-grasses by hand separation. The grass plants were sorted by species while the non-grass herbaceous was combined as forbs. The samples were oven-dried at $105^{\circ} \mathrm{C}$ for 24 hours and weighed in order to determine the dry matter content.

Stastical analysis: The frequency of each herbaceous species, including that of bare ground, was expressed as a percentage of the total number of points. The proportion of the different grass species according to their desirability was calculated using percentage. The experimental units in communal grazing area, 8 sample plots and enclosure area, 4 sample plots was used for the analysis.

\section{Results and Discussion}

\section{Herbaceous species composition}

A total of 13 species of grasses, 2 species of legumes, and 4 species of other herbaceous plants were identified in the study district. Of the grass species, $15.3 \%, 30.8 \%, 38.6 \%$ and $15.3 \%$ were highly desirable, desirable, less desirable and undesirable respectively. The less desirable and undesirable grass species increase in the vegetation due to severe over grazing and they are generally indicators of declining range condition Van oudtshoom, 1999. The data obtained from the dry matter production were subjected to ANOVA using the GLM procedure of Statistical [5] computer software. ANOVA was used with the interaction for dry matter biomass versus grazing areas. Significant differences were detected with $\mathrm{P}<0.05$ and means were separated by Duncan's Multiple Range Test (DMRT) Table 1.

Chrysopogon plumolosus, Tragus berteronianus and Brachiaria dictyneura were some of the dominant and/or common grass species found in communal grazing areas while Cenchrus ciliaris, Eragrostis teniufolia, C. plumolosus and Cynodon dactylon were among the dominant/or common grass species found in Enclosure areas. Most of the grass species found in the enclosure areas such as $C$. dactylon and $C$. plumolosus are drought and heavy grazing tolerant which in line with the reports of [6] and Amsalu and Baars 2002 and C. ciliaris are highly palatable and indicators of good rangeland condition Van oudtshoom, 1999. These grass species were to be found on enclosure areas, very important feeds for cattle, and cows fed on them used to give a good milk yield but currently these species were found very rarely and even on the verge of extinction from most of the communal grazing areas.

The "extinction" of most valuable grasses and their replacement by less important annuals was also reported in the work of [7] and had become a common phenomenon in most part of Afar Region. As reported in the works of [8] Ayana (1999) [9] heavy grazing pressure might have caused a decline in plant species composition and diversity over time. In addition, Ahmed (2003) and [10] have confirmed that species composition could be negatively correlated with increased rangeland deterioration.

\section{Enclosure area}

In the enclosure areas, highly desirable grass species such as $C$. ciliaris, and C. dactylon desirable grass specie like C. plumolosus, Sporobolus pyramidallis, Eragrostis teniufolia and Aristida adoenesis were some of the dominant and/or common grass species. Among the highly desirable grass species that were identified only in enclosure area of the study district were C. ciliaris and C. dactylon, whereas the identified desirable species found in both grazing areas but the relative occurrence was higher in the enclosure area. The dominance of perennial grasses may indicate that the herbaceous layer was in good

\begin{tabular}{|c|c|c|c|}
\hline Species & Cg (use values) & Enclosure & Communal \\
\hline \multicolumn{4}{|c|}{ Grasses } \\
\hline Brachiaria dictyneura & UD & - & C \\
\hline Cenchrus ciliaris & $\mathrm{HD}$ & $\mathrm{D}$ & - \\
\hline Eleusine multifolia & LD & - & $\mathrm{P}$ \\
\hline Eragrostis teniufolia & $D$ & C & $P$ \\
\hline Chloris prieurii & LD & $P$ & $P$ \\
\hline Chrysopogon plumolosus & D & C & D \\
\hline Sporobolus pyramidallis & $\mathrm{D}$ & $P$ & $P$ \\
\hline Cynodon dactylon & HD & C & - \\
\hline Tragus beteronianus & UD & - & D \\
\hline Lintonia nutans & LD & - & $P$ \\
\hline Aristida adoenesis & $\mathrm{D}$ & $P$ & - \\
\hline Brachiaria sp. & LD & - & $P$ \\
\hline Eragrostis cilianensis & LD & - & $P$ \\
\hline \multicolumn{4}{|c|}{ Legumes } \\
\hline Crotalaria incana & $\mathrm{D}$ & C & - \\
\hline Indigofera spinosa & LD & - & $\mathrm{P}$ \\
\hline \multicolumn{4}{|c|}{ Others/forbs } \\
\hline Blephris ciliaris & LD & $P$ & $P$ \\
\hline Ocimum lamifoliu & HD & $P$ & - \\
\hline Sida ovata & LD & $\mathrm{P}$ & $P$ \\
\hline Tribulis terrestris & LD & - & C \\
\hline
\end{tabular}

Note: $\mathrm{Cg}=$ Categories; $\mathrm{C}=$ Communal grazing areas; $\mathrm{E}=$ Enclosure; $\mathrm{HD}=$ Highly desirable; $\mathrm{D}=$ Desirable; $\mathrm{LD}=$ Less desirable; $U D=$ Undesirable; $\mathrm{D}=$ Dominant $(>20 \%)$; $C=$ Common $(10-20 \%) ; P=$ Present $(<10 \%$ of the total herbaceous plant $)$ and - =Absen

Table 1: Herbaceous species composition, use values and relative abundance in different grazing areas of Ewa woreda of Afar Region. 
condition [11]. Similar results were reported by Mohammed (2009), Noy-Meir et al. (1989) and De-Val and Crawley (2005) indicating that in protected areas highly desirable perennial grasses were found to be abundant.

According to the opinion of the herds' man, the present grass species, which were found in the communal grazing lands, were not similar to the endangered grass species (mostly perennial plants) in quality and quantity. They compared the present and the past species in terms of livestock products and body condition. In the past, grass species had a high yield and nutritive quality that increases milk production and live weight gain (fattening) and also used as other purpose like house making. Due to this fact, milk, butter and meat availability were very high and the livestock sale was also good. But, the existing plant species found in the communal grazing areas have less influence on the milk and meat production as well as animal body performance. Most of the grass species in communal grazing areas are light in weight and easily diminished within a short period of time after growing.

\section{Communal grazing areas}

The desirable grass species C. plumolosus was the only species that dominated in the communal grazing area and C. plumolosus is tolerant to drought and heavy grazing due to its high regeneration capacity, it is useful in controlling erosion and recovers easily from intense grazing Kidane, 2000. The less desirable grass species Eleusine multifolia, Chloris prieurii, Lintonia nutans, Brachiaria sp. and Eragrostis cilianensis were abundant in the communal grazing areas.

Brachiaria dictyneura and Tragus berteronianus were commonly and/or dominantly found in communal grazing areas. The grass species T. beteronianus has been known to be of poor grazing value due to the low leaf production; it might increases with overgrazing and is therefore an indicator of rangeland deterioration. Most of the grass species grown in the communal rangeland were annuals and low abundant of perennial grasses this show that the most important grass species especially perennial grasses were near to extinct totally from the communal grazing area of the study district this might be due to overgrazing and recurrent drought.

According to Naithani, et al., 1993 and Sabernwal 1996, grazing pressure maintains low species diversity and grazing animals' decreases species diversity through the removal of palatable plant species or trampling by hooves, soil compaction, urination and dung deposition. The degree of grazing strongly affects the structure, composition, quality and productivity of rangeland vegetation [12]. Furthermore, Premise (1995) stated that an increase of less desirable and undesirable perennial species and decrease of desirable species are important indicators of rangeland deterioration.

The result revealed that, due to widespread grazing pressure and recurrent drought in the area, it was difficult to find out the potential distribution of untouched vegetation because ungrazed lands was extremely rare except in APARI enclosure site and some voluntary pastoralists enclosure sites. High grazing pressure and low level of green forage were noticed everywhere and all green forages available had been eaten by domestic grazing animals consequently forage shortage was very severe during the dry season.

\section{Biomass production}

The enclosures had a significantly $(\mathrm{P} \leq 0.05)$ higher biomass of total grass $(\mathrm{Tgb})$ and total herbaceous (Thb) than the Communal grazing types, but there was no significant difference between two grazing types in terms of total non-grass biomass. The Thb value ranged for the enclosures from $58.6 \mathrm{~kg} / \mathrm{ha}$ to $92 \mathrm{~kg} / \mathrm{ha}$ while in the communal grazing areas ranged from $20.1 \mathrm{~kg} / \mathrm{ha}$ to $50.5 \mathrm{~kg} / \mathrm{ha}$. The value for the total grass biomass and non-grass biomass in the enclosure areas ranged from 49.7 $\mathrm{kg} / \mathrm{ha}$ to $80.7 \mathrm{~kg} / \mathrm{ha}$ and $0 \mathrm{~kg} / \mathrm{ha}$ to $15.3 \mathrm{~kg} / \mathrm{ha}$, respectively, whereas in the communally grazing areas the total grass biomass and non-grass biomass ranged from $18.6 \mathrm{~kg} / \mathrm{ha}$ up to $38.2 \mathrm{~kg} / \mathrm{ha}$ and $0 \mathrm{~kg} / \mathrm{ha}$ to 17.2 $\mathrm{kg} / \mathrm{ha}$, respectively [13]. The biomass production in the enclosure grazing areas better than the communal grazing areas this might be due to better rangeland management practices in the enclosure areas but the communal grazing areas have deteriorate through continuous overgrazing and mismanagement system of the community, which is in need of immediate intervention by making area closure or resting highly degraded grazing areas in order to recover the species composition of the grazing areas within a short period of time and also for the sustainable livestock production of the study district. According to pastoralists disclosed that, the rainfall patter of the study district for the last five years were not good as compare to the other areas this is mostly contribute its share for the declining of dry matter production Table 2 .

\section{Conclusion and Recommendation}

From this finding, it can be concluded that the enclosure areas have been effective in restoring plant species composition, biomass and cover of herbaceous species and the enclosure areas were in a better condition than the communal grazing areas. Most of the grass species found in the enclosure areas are perennial and desirable by livestock but vast area of the communal grazing areas were covered by less desirable and invader species, which are not grazed by livestock so the enclosure areas need a sustainable maintenance of their present condition, while the communal grazing areas are in need of improvement interventions. Range species composition of the study area, is subjected to extinction due to overgrazing and rangeland mismanagement practices of the community. Most of the communal grazing areas were found in the study area to be heavily grazed in such a way that, the less proportion of vegetation are become visible and there are bare patches in between where the land is exposed to various erosion [14].

Therefore, establishment of community based enclosures or resting and also re-seeding highly denuded grazing areas is very important to improve the species composition and biomass production of the study area however, before making enclosure local communities should be consulted and take the initiative of local herders is the basis for decision making in the utilization and management of grazing lands. So that, continuous awareness rising through training is play vital roles in order to enhance the traditional knowledge of the pastoralists. Additionally, conserving endangered species through seed collection and multiplication are vital to improve the rangeland vegetation composition of the communal grazing areas.

\begin{tabular}{|c|c|c|}
\hline Parameters & Enclosure & Communal \\
\hline Tgb & $61.99 \pm 1.81^{\mathrm{a}}$ & $30.50 \pm 1.28^{\mathrm{b}}$ \\
\hline Tngb & $8.62 \pm 1.16^{\mathrm{a}}$ & $7.57 \pm 0.82^{\mathrm{a}}$ \\
\hline Thb & $70.61 \pm 2.05^{\mathrm{a}}$ & $38.08 \pm 1.45^{\mathrm{b}}$ \\
\hline
\end{tabular}

Tgb=Total grass biomass, Tngb=Total non-grass biomass, Thb=Total herbaceous Biomass; Means with different letters in a row are significantly different at $(\mathrm{P} \leq$ 0.05)

Table 2: Biomass production (LSM and SE) of the two grazing areas of Ewa woreda of Afar Region State 
Citation: Ibrahim MA (2016) Impact of Enclosure on Plant Species Composition and Biomass Production in Ewa Woreda of Afar Region State, Ethiopia. J Biodivers Endanger Species 4: 157. doi:10.4172/2332-2543.1000157

\section{Acknowledgement}

I would like to extend my heart full thanks to Afar Pastoral and Agro-pastoral Research Institute (APARI) to provide financial and material support in orde carried out this research work.

\section{References}

1. Abdulatife M, Tesfu Kassaye (2009) Indigenous Rangeland Management Knowledge of the pastoralists of Dalifaghe district in Afar Region, Ethiopia.

2. Afar Pastoral A, Agricultural and Development Beuro (APADB) (2006) Baseline survey made on the Potential, Constraints, and Opportunity on the Production System of 29 woredas of Afar National Regional State.

3. International Livestock Center for Africa (1990) Livestock system research manual.No.12, section 1. Working document used in range management. ILCA Addis Ababa, Ethiopia. Society of range management, Denver, Colorado, USA

4. Amsalu S, Baars RMT (2002) Grass composition and rangeland condition of the major grazing areas in the mid rift valley, Ethiopia. African Journal of Range and Forage Science 19: 161-166.

5. Statistical Analysis System Institute Inc., (2001) Applied statistics and the SAS programming language $2^{\text {nd }}$ edition Cary, North Carolina.

6. Adane K (2003) Effect of stage of harvesting and fertilizer application on dry matter yield and quality of natural grasslands in the highlands of north Shao oromia. An MSc. Thesis Presented to the School of Graduate Studies of Haramaya University, p. 96.
7. Abdulatife $\mathrm{M}$ (2009) Assessment of pastoral perceptions, range condition and chemical composition of major feed resources in Chifra district of afar Regional State. An MSc Thesis, Haramaya University.

8. Baars RMT, Chileshe EC, Kalokoni DR (1997) Technical notes: Range condition in high cattle density areas in the Western Province of Zambia. Tropical Grasslands 31: 569-573

9. Amsalu S (2001) Herbaceous species composition, dry matter production, and condition of the major grazing areas in the mid rift valley of Ethiopia. An MSc thesis, Presented to the School of Graduate Studies of Alemaya University, Dira dewa Ehiopia, p. 95

10. Admasu T (2006) Pastoralists Perceptions on Range-Livestock Management Practices and Rangeland Assessment in Hamer and Benna-Tsemay Districts of South Omo Zone. School of Graduate Studies of Haramaya University.

11. O'Connor TG, Pickett (1992) The influence of grazing on seed production and seed banks of some African Savanna grasslands.Journal of Applied Ecology 29: $247-260$

12. Herlocker D (1999) Rangeland Resources in Eastern Africa: Their Ecology and Development. GTZ, German Technical Cooperation, Nairobi.

13. Ahmed Hassen (2006) Assessment and evaluation of utilization practices of natural pastures and other forages in BasonaWorana wereda of North Shoa Zone. School of Graduate Studies of Alemaya University, Ethiopia, p. 174.

14. Central Statistical Authority (CSA) (2007) Ethiopian Statistical Abstract, Central Statistical Authority, Addis Ababa Ethiopia. 